\title{
Meta Analysis the Effect of Acupuncture Therapy on Pain Reduction in Osteoarthritis Patients
}

\author{
Fahmi Eko Susilo'), Agus Kristiyanto), Hanung Prasetya3)
}

\author{
1)Masters Program in Public Health, Universitas Sebelas Maret \\ 2)Sports and Health Education Study Program, Universitas Sebelas Maret \\ 3)Study Program in Acupuncture, Health Polytechnics, Ministry of Health Surakarta
}

\section{ABSTRACT}

Background: Osteoarthritis (OA) is the most common joint condition and is characterized by progressive erosion of the articular cartilage. Based on data from Basic Health Research (2018) the prevalence of joint disease in Indonesia is recorded at around $7.3 \%$ and osteoarthritis (OA) or arthritis is a common joint disease. As the two main nonsurgical methods, physiotherapy and acupuncture have been shown to be safe and effective in the therapy of osteoarthritis.

Subjects and Method: This was a systematic review and meta-analysis study. The articles used in this study were obtained from several databases including PubMed, Google Scholar, and Springer Link. The articles used in this study were those published from 2000-2020. The article search was carried out by considering the eligibility criteria defined using the PICO model. The population in the study were patients with osteoarthritis complaints with intervention in the form of acupuncture therapy, the comparison was the sham acupuncture outcome in the form of pain reduction. The keywords for finding articles are as follows: "Acupuncture"
OR "Osteoarthritis" AND "Randomized Controlled Trials". The articles included in this study are full text articles with an observational study design. Articles were collected using PRISMA flow diagrams. Articles were analyzed using the Review Manager 5.3 application.

Results: A total of 9 articles were reviewed in this study. A meta-analysis of 9 randomized control trials showed that acupuncture therapy reduced pain in osteoarthritis patients $(\mathrm{SMD}=-0.49 ; 95 \% \mathrm{CI}=-0.88$ to -0.10 ; $\mathrm{p}=0.01)$.

Conclusion: Acupuncture therapy reduces pain in osteoarthritis patients.

Keywords: acupuncture, osteoarthritis, acupuncture osteoarthritis, randomized contro trial

\section{Correspondence:}

Fahmi Eko Susilo. Masters Program in Public Health. Universitas Sebelas Maret, Jl. Ir. Sutami 36A, Surakarta 57126, Central Java. Email: fahmiekss@gmail.com. Mobile: o81393644991.

\section{Cite this as:}

Susilo FE, Kristiyanto A, Prasetya H (2021). Meta Analysis the Effect of Acupuncture Therapy on Pain Reduction in Osteoarthritis Patients. Indones J Med. 06(01): 95-103. https://doi.org/10.26911/theijmed.2021.06.01.10.

\section{BACKGROUND}

Osteoarthritis (OA) is the most common joint condition and is characterized by progressive erosion of the articular cartilage. Clinically, patients who experience pain due to excessive pressure or physical exertion are relieved by rest, but in the final stages, patients experience pain even at rest, they lose function, with limited movement and difficulty in carrying out daily activities (Ralph Plaster, 2014 ).

Based on data from Basic Health Research (2018) the prevalence of joint disease in Indonesia is recorded at around 
$7.3 \%$ and osteoarthritis (OA) or arthritis is a common joint disease.

The number of primary studies examining the effect of acupuncture therapy on pain reduction in osteoarthritis patients encouraged researchers to conduct a more comprehensive study of these primary studies. The data obtained were analyzed using a systematic review and meta-analysis by synthesizing the results of studies conducted to reduce bias.

\section{SUBJECTS AND METHOD \\ 1. Study Design}

This was a systematic review and meta-analysis study. The articles used in this study were obtained from several databases including PubMed, Google Scholar, and Springer Link. The keywords for finding articles are as follows: "acupuncture" OR "osteoartritis" AND "randomized controlled trials"

\section{Inclusion Criteria}

The articles included in this study are full paper articles with a Randomized Control Trial study design, in Indonesian and English. Appropriate articles should mention acupuncture therapeutic interventions with pain reduction outcomes.

The article used an appropriate population of patients with osteoarthritis complaints.

\section{Exclusion Criteria}

The articles published in this study were articles that have been carried out by metaanalysis. Articles published before 1999 and not full-papers.

\section{Operational Definition}

Article searches were carried out by considering the eligibility criteria defined using the PICO model. The population of patients with osteoarthritis conditions with intervention in the form of acupuncture therapy, comparison of sham acupuncture outcomes in the form of pain reduction.
Knee osteoarthritis is a degenerative disease of cartilage, but recent evidence has shown that $\mathrm{OA}$ is multifactorial. It involves several factors such as trauma, inflammation, biochemical reactions and metabolic damage (Mora, 2018).

Acupuncture therapy is a therapeutic treatment by inserting needles into acupuncture points in the human body. Another technique of acupuncture therapy is acupressure therapy which is a therapy by doing massage using the fingers of the acupoints that have been mapped on the human body (Saputra and Sudirman, 2009).

\section{Data Analysis}

Data processing was carried out by the Review Manager (RevMan 5.3) by calculating the effect size and heterogeneity to determine which study models were combined and formed the final meta-analysis result.

\section{RESULTS}

The process articles search was done by searching through a database with journals that can be seen in Figure 1. Figure 2 shows the areas where articles were taken according to the inclusion criteria. Articles obtained from 4 continents, namely Asia, America, Europe and Australia.

Based on the results of the forest plot (Figure 3), acupuncture therapy reduced pain in osteoarthritis patients by -0. 49 and it was statistically significant $(\mathrm{p}=0.01)$. The heterogeneity of the study data showed $\mathrm{I}^{2}=$ $94 \%$. The distribution of the data was stated to be heterogeneous (random effect model). The funnel plot (Figure 4) showed that there was a publication bias which was characterized by asymmetry of the two plots. On the left there were 3 plots, in the middle of the line there was 1 plot and on the right there were 5 plots. 
Susilo et al./ Effect of Acupuncture Therapy on Pain Reduction in Osteoarthritis Patients

Based on the assessment of the quality of the study using the critical appraisal checklist for Randomized Control Trial, 9 articles included in the quantitative synthesis of the meta-analysis of the majority qualify in the assessment of study quality.

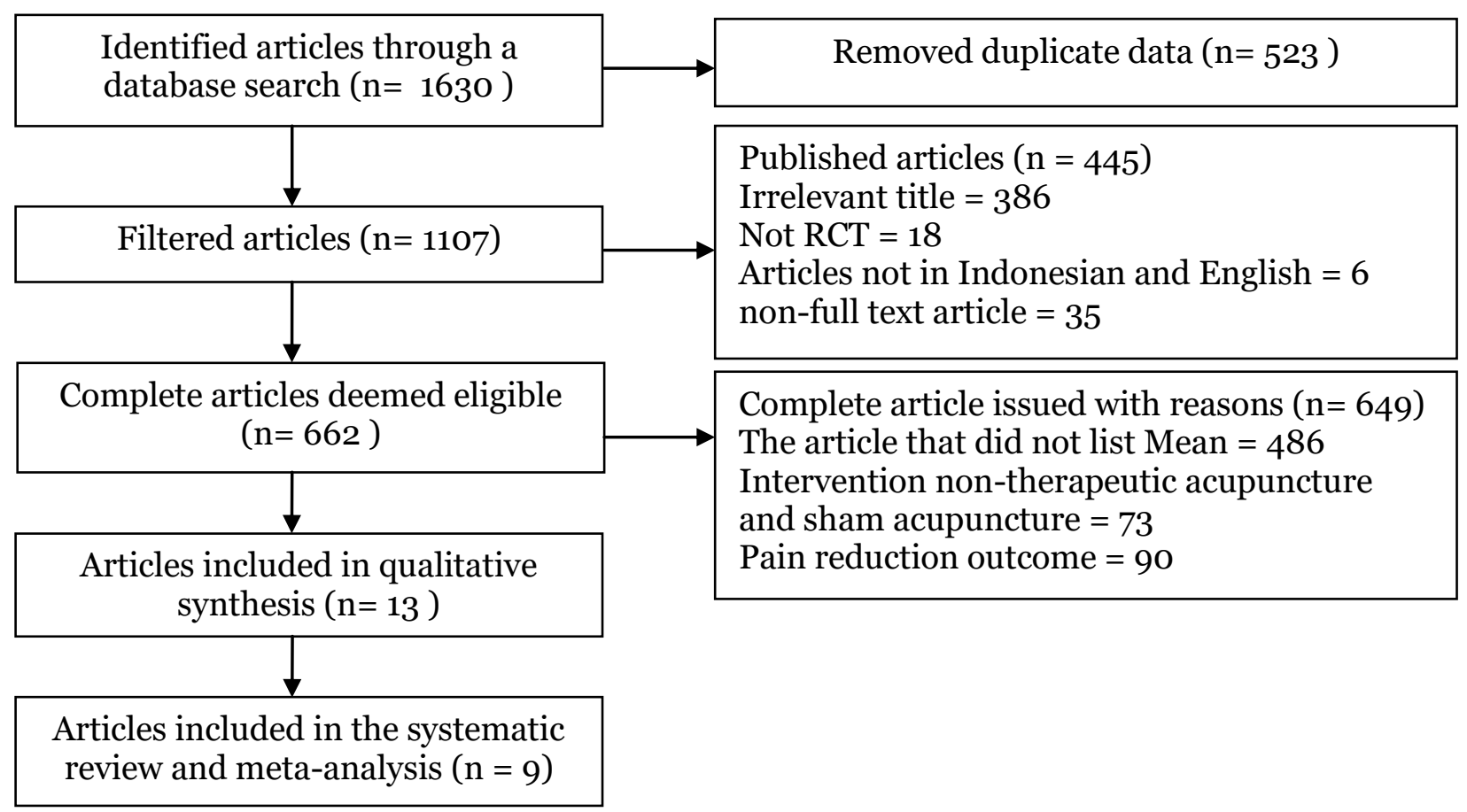

Figure 1. PRSMA Flow Diagram 
Table1. Primary study descriptions included in the meta-analysis

\begin{tabular}{|c|c|c|c|c|c|c|}
\hline $\begin{array}{c}\text { Author } \\
\text { (year) }\end{array}$ & Articles Title & Country & Sample & Population & $\begin{array}{l}\text { Comparison } \\
\text { Intervention }\end{array}$ & Outcome \\
\hline $\begin{array}{l}\text { Scharf HP, et } \\
\text { al } 2006\end{array}$ & $\begin{array}{l}\text { Acupuncture and Knee Osteoarthritis } \\
\text { A Three-Armed Randomized Trial }\end{array}$ & German & 1007 & $\begin{array}{l}\text { People with } \\
\text { knee } \\
\text { osteoarthritis }\end{array}$ & $\begin{array}{l}\text { I : Acupuncture } \\
\text { C: Sham } \\
\text { Acupuncture }\end{array}$ & $\begin{array}{l}\text { Pain } \\
\text { reduction }\end{array}$ \\
\hline $\begin{array}{l}\text { Foster NE et } \\
\text { al, } 2007\end{array}$ & $\begin{array}{l}\text { Acupuncture as an adjunct to exercise based } \\
\text { physiotherapy for osteoarthritis of the knee: } \\
\text { randomised controlled trial }\end{array}$ & $\begin{array}{l}\text { Midlands, } \\
\text { England }\end{array}$ & 352 & $\begin{array}{l}\text { People with } \\
\text { knee } \\
\text { osteoarthritis }\end{array}$ & $\begin{array}{l}\text { I : Acupuncture } \\
\text { C: Sham } \\
\text { Acupuncture }\end{array}$ & $\begin{array}{l}\text { Pain } \\
\text { reduction }\end{array}$ \\
\hline $\begin{array}{l}\text { Almazor MES } \\
\text { et al, } 2010\end{array}$ & $\begin{array}{l}\text { A Randomized Controlled Trial of Acupuncture } \\
\text { for Osteoarthritis of the Knee: Effects of Patient } \\
\text { Provider } \\
\text { Communication }\end{array}$ & $\begin{array}{l}\text { Texas, } \\
\text { America }\end{array}$ & 455 & $\begin{array}{l}\text { People with } \\
\text { knee } \\
\text { osteoarthritis }\end{array}$ & $\begin{array}{l}\text { I : Acupuncture } \\
\text { C: Sham } \\
\text { Acupuncture }\end{array}$ & $\begin{array}{l}\text { Pain } \\
\text { reduction }\end{array}$ \\
\hline $\begin{array}{l}\text { Witt } \mathrm{C} \text { et al, } \\
2005\end{array}$ & $\begin{array}{l}\text { Acupuncture in patients with osteoarthritis of } \\
\text { the knee: } \\
\text { a randomised trial }\end{array}$ & $\begin{array}{l}\text { Berlin, } \\
\text { German }\end{array}$ & 294 & $\begin{array}{l}\text { People with } \\
\text { knee } \\
\text { osteoarthritis }\end{array}$ & $\begin{array}{l}\text { I : Acupuncture } \\
\text { C: Sham } \\
\text { Acupuncture }\end{array}$ & $\begin{array}{l}\text { Pain } \\
\text { reduction }\end{array}$ \\
\hline $\begin{array}{l}\text { Berman MB et } \\
\text { al, } 2004\end{array}$ & $\begin{array}{l}\text { Effectiveness of Acupuncture as Adjunctive } \\
\text { Therapy in Osteoarthritis of the Knee }\end{array}$ & $\begin{array}{l}\text { Maryland, } \\
\text { North } \\
\text { America }\end{array}$ & 570 & $\begin{array}{l}\text { People with } \\
\text { knee } \\
\text { osteoarthritis }\end{array}$ & $\begin{array}{l}\text { I : Acupuncture } \\
\text { C: Sham } \\
\text { Acupuncture }\end{array}$ & $\begin{array}{l}\text { Pain } \\
\text { reduction }\end{array}$ \\
\hline $\begin{array}{l}\text { Hinman RS et } \\
\text { al, } 2014\end{array}$ & $\begin{array}{l}\text { Acupuncture for Chronic Knee Pain } \\
\text { A Randomized Clinical Trial }\end{array}$ & Australia & 282 & $\begin{array}{l}\text { People with } \\
\text { knee } \\
\text { osteoarthritis }\end{array}$ & $\begin{array}{l}\text { I : Acupuncture } \\
\text { C: Sham } \\
\text { Acupuncture }\end{array}$ & $\begin{array}{l}\text { Pain } \\
\text { reduction }\end{array}$ \\
\hline $\begin{array}{l}\text { Lin LL et al, } \\
2018\end{array}$ & $\begin{array}{l}\text { Effectiveness and feasibility of acupuncture for } \\
\text { knee osteoarthritis: a pilot randomized } \\
\text { controlled trial }\end{array}$ & $\begin{array}{l}\text { Beijing, } \\
\text { China }\end{array}$ & 42 & $\begin{array}{l}\text { People with } \\
\text { knee } \\
\text { osteoarthritis }\end{array}$ & $\begin{array}{l}\text { I : Acupuncture } \\
\text { C: Sham } \\
\text { Acupuncture }\end{array}$ & $\begin{array}{l}\text { Pain } \\
\text { reduction }\end{array}$ \\
\hline Liu et al, 2020 & $\begin{array}{l}\text { Efficacy of intensive acupuncture versus sham } \\
\text { acupuncture in knee osteoarthritis: A } \\
\text { randomized controlled trial }\end{array}$ & $\begin{array}{l}\text { Beijing, } \\
\text { China }\end{array}$ & 442 & $\begin{array}{l}\text { People with } \\
\text { knee } \\
\text { osteoarthritis }\end{array}$ & $\begin{array}{l}\text { I : Acupuncture } \\
\text { C: Sham } \\
\text { Acupuncture }\end{array}$ & $\begin{array}{l}\text { Pain } \\
\text { reduction }\end{array}$ \\
\hline $\begin{array}{l}\text { Xu Hong, } \\
\text { Ryan DJ, Li K, } \\
2007\end{array}$ & $\begin{array}{l}\text { Acupuncture in the Management of the } \\
\text { Symptoms of Osteoarthritis of the Knee: A } \\
\text { Preliminary, Single-blind and Sham-controlled } \\
\text { Study }\end{array}$ & Australia & 36 & $\begin{array}{l}\text { People with } \\
\text { knee } \\
\text { osteoarthritis }\end{array}$ & $\begin{array}{l}\text { I : Acupuncture } \\
\text { C: Sham } \\
\text { Acupuncture }\end{array}$ & $\begin{array}{l}\text { Pain } \\
\text { reduction }\end{array}$ \\
\hline
\end{tabular}

*Variables included in the meta-analysis study 
Table 2. Study Quality Assessment of Randomized Control Trial

\begin{tabular}{|c|c|c|c|c|c|c|c|c|c|}
\hline \multirow[b]{2}{*}{ Checklist Questions } & \multicolumn{9}{|c|}{ Publication (Author and Year) } \\
\hline & $\begin{array}{l}\text { Scharf } \\
\text { et al. } \\
(2006)\end{array}$ & $\begin{array}{l}\text { Foster } \\
\text { et al. } \\
(2007)\end{array}$ & $\begin{array}{l}\text { Almazor } \\
\text { et al. } \\
\text { (2010) }\end{array}$ & $\begin{array}{l}\text { Witt et } \\
\text { al. } \\
(2005)\end{array}$ & $\begin{array}{l}\text { Berman } \\
\text { et al. } \\
(\mathbf{2 0 0 4 )}\end{array}$ & $\begin{array}{l}\text { Hinman } \\
\text { et al. } \\
\text { (2014) }\end{array}$ & $\begin{array}{l}\text { Lin et } \\
\text { al. } \\
(\mathbf{2 0 1 8})\end{array}$ & $\begin{array}{l}\text { Liu et } \\
\text { al. } \\
\text { (2020) }\end{array}$ & $\begin{array}{c}\text { Xu et } \\
\text { al. } \\
(\mathbf{2 0 0 7 )}\end{array}$ \\
\hline ady address a clear study focus? & 1 & 1 & 1 & 1 & 1 & 1 & 1 & 1 & 1 \\
\hline $\begin{array}{l}\text { omized Controlled Trial study } \\
\text { table for answering study }\end{array}$ & 1 & 1 & 1 & 1 & 1 & 1 & 1 & 1 & 1 \\
\hline $\begin{array}{l}\text { nough subjects in the study to } \\
\text { at the findings were not made by }\end{array}$ & 1 & 1 & 1 & 1 & 1 & 1 & 1 & 1 & 1 \\
\hline $\begin{array}{l}\text { s randomly allocated to the } \\
\text { al and control groups? If not, } \\
\text { e biased? }\end{array}$ & 1 & 1 & $\mathrm{O}$ & 1 & 1 & 1 & 1 & 1 & 1 \\
\hline n/exclusion criteria used? & 1 & 1 & 1 & 1 & 1 & 1 & 1 & 1 & 1 \\
\hline groups comparable at study & O & o & O & $\mathrm{O}$ & O & O & O & O & O \\
\hline ve and unbiased outcome criteria? & 1 & 1 & 1 & 1 & 1 & 1 & 1 & 1 & 1 \\
\hline ve and validated measurement & 1 & 1 & 1 & 1 & 1 & 1 & 1 & 1 & 1 \\
\hline
\end{tabular}

Does this study address a clear study focus?

Is the Randomized Controlled Trial study method suitable for answering study

questions?

Are there enough subjects in the study to establish that the findings were not made by chance?

Are subjects randomly allocated to the experimental and control groups? If not, could this be biased?

Are inclusion/exclusion criteria used? Are the two groups comparable at study entry?

Are objective and unbiased outcome criteria? Are objective and validated measurement methods used to measure the results? If not, were the results scored by someone who did not know the group assignment (i.e. was the grading blended)?

Is the effect size practically relevant?

How precise is the estimated effect? Is there a

confidence interval?

Could there be confounding factors that have

not been taken into account?

Are the results applicable to your study?

Total

Information

Yes $=1$

$\mathrm{No}=\mathrm{O}$ 
Susilo et al./ Effect of Acupuncture Therapy on Pain Reduction in Osteoarthritis Patients

1. The Effect of Acupuncture Therapy on Pain Reduction in Osteoarthritis Patients a. ForestPlot

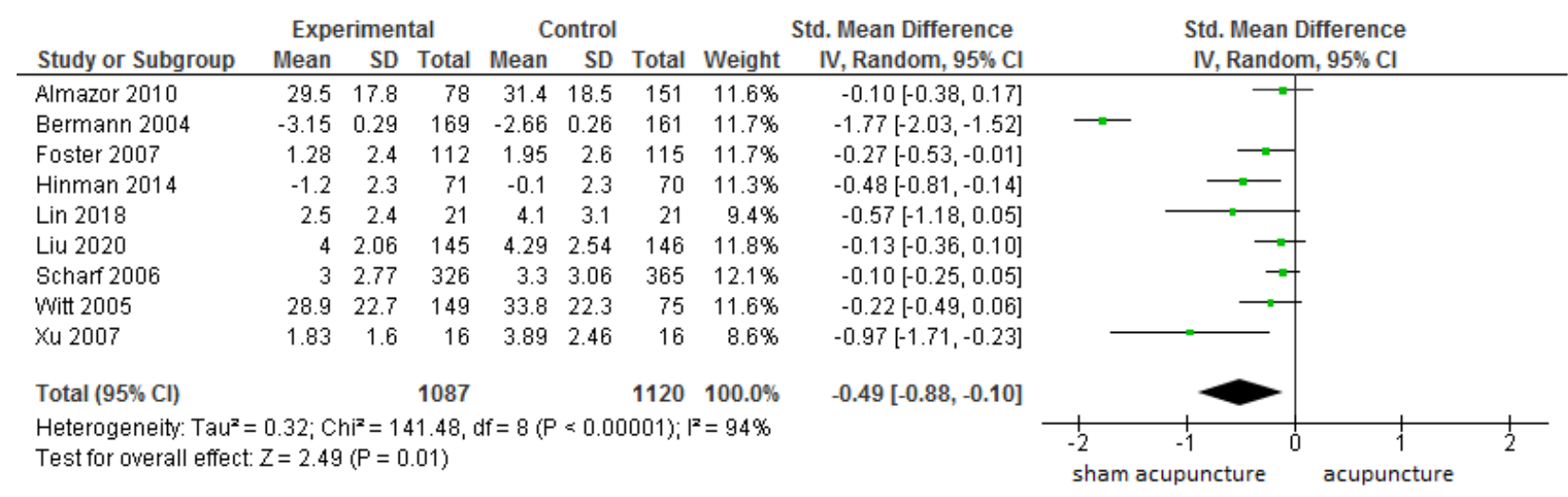

Figure 3.Forest Plot of the Effect of Acupuncture Therapy on Pain Reduction in Osteoarthritis Patients

\section{b. Funnel Plot}

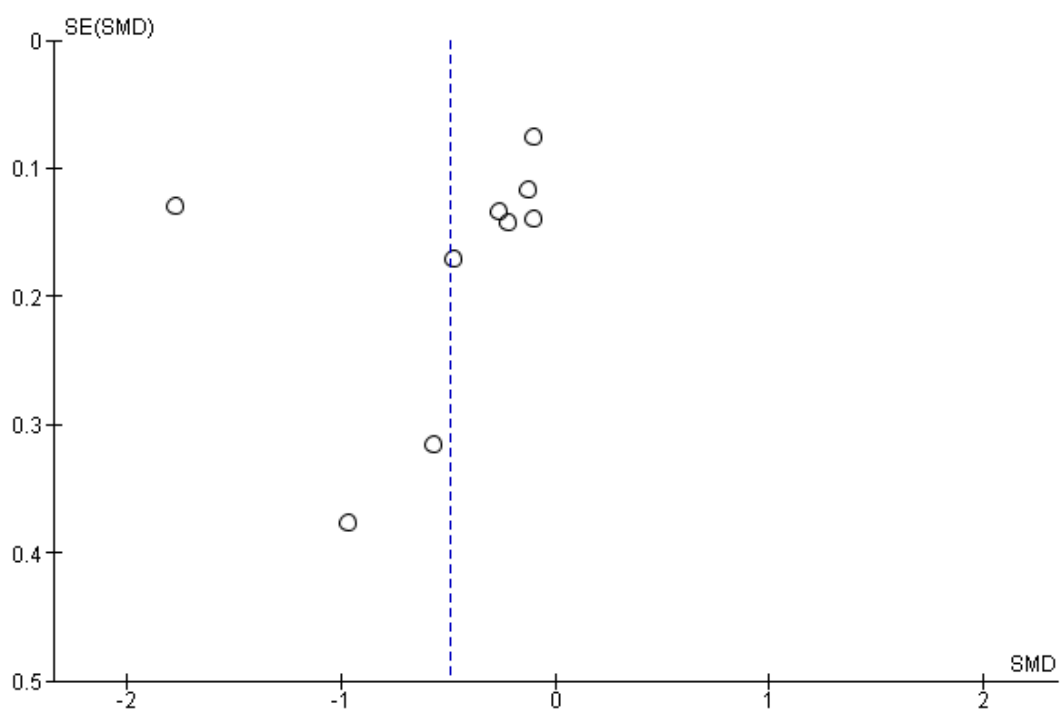

\section{Figure4. Funnel Plot of the Effect of Acupuncture Therapy on Pain Reduction in Osteoarthritis Patients}

\section{DISCUSSION}

As a type of joint disease osteoarthritis (OA) is characterized by the degradation of cartilage, which can occur in any joint, especially in weight-bearing joints. The knee joint is considered to be the most frequently complained place in the clinic. Two therapeutic methods can now be available to treat OA: surgery and nonsurgical therapy. However, surgery is reported to be suit- able for patients at an advanced stage, and non-operative therapy, especially for patients at an early or middle stage. As the two main non-surgical methods, physiotherapy and acupuncture have been shown to be safe and effective in the treatment of OA (Zhang et al, 2016).

This systematic review and metaanalysis study raised the theme of the effect of acupuncture therapy on pain reduction 
in osteoarthritis patients. This study discussed data on acupuncture therapy for osteoarthritis considered important because of its rarity. The number of relevant research published and accessible is still small and also has data access problems (data duplication) (Murti, 2018). Confounding factors affect the relationship or effect of exposure to the occurrence of disease estimated (estimated) by the study is not the same as the relationship or effect that actually occurs in the target population (invalid) study results (Murti, 2018). This systematic study and meta-analysis study used studies that has controlled for confounding factors which can be seen from the study inclusion requirements, namely the standardized mean difference.

Estimates of the combined effect of acupuncture therapy were processed by using RevMan 5.3 with the Continous method. This method was used to analyze the effect size or standardized mean differrence in the bivariate data of two groups that had been controlled for confounding factors by randomization.

The results of the systematic study and meta-analysis are presented in the form of a forest plot and a funnel plot. The forest plo provide an overview of information from each of the studies investigated in the meta-analysis, and estimates of the overall results (Murti, 2018).

A funnel plot is a diagram in a metaanalysis used to demonstrate possible publication bias. Funnel plots show the relationship between funnel plots that visually show the amount of variation (heterogeneity) (Akobeng, 2005 in Murti, 2018). The funnel plot shows the relationship between the effect size of the study and the sample size of the various studies under study, which can be measured in a number of different ways (Murti, 2018).
There were 9 articles of randomized control trial as a source of meta-analysis of the effect of acupuncture therapy on pain reduction in osteoarthritis patients. The results of the meta-analysis showed that acupuncture therapy could reduce pain in osteoarthritis patients by - 0.49 times (CI $95 \%-0.88$ to $-10, \mathrm{p}=0.01$ )

This is supported by Jubb et al. (2015) which stated that acupuncture reduced pain in osteoarthritis patients compared to sham acupuncture. In addition, acupuncture provides symptom improvement for patients with knee osteoarthritis, and is significantly superior to sham acupuncture.

This study is in line with Zhao et al., (2010) which stated that osteoarthritis patients who received acupuncture therapy experienced a decrease in pain compared to patients who received acupuncture sham. However, there was no significant differrence between the two groups in physical function scores.

Another study conducted by Manheimer et al., (2007) stated that compared to sham controls, acupuncture showed statistically significant, short-term osteoarthritis pain.

This study is confirmed that acupuncture can reduce pain by increasing the degeneration of mesenchymal cells in the bone marrow which functions to stimulate the proliferation or cell formation cycle in cartilage (chondrocytes) so that it can reduce inflammation or pain in the knee (Wang et al, 2020). Haryanto JT, et al (2017) stated that one of the most effective treatments to reduce the pain scale is by using acupuncture therapy.

The results of this study indicate that patients with osteoarthritis complaints show a decrease in pain after receiving acupuncture therapy. Knee pain scale reduction using acupuncture therapy Jin's 3 Needle by sticking the Xiyan (extra), 
Xuehai (SP 10) and Liangqiu points (ST 34).

\section{AUTHOR CONTRIBUTION}

Fahmi is the main researcher who selected topics, searched and collected the data. Agus Kristiyanto and Hanung Prasetya have roles in analyzing data and reviewing study documents.

\section{CONFLICT OF INTEREST}

There was no conflict of interest in this study.

\section{FUNDING AND SPONSORSHIP}

This study is self-funded.

\section{ACKNOWLEDGEMENT}

We are very thankful to the database providers of PubMed, Google Scholar, and Springer Link.

\section{REFERENCE}

Almazor MES, Looney C, Liu Y, Cox V,Pietz K, Marcus DM, Street (2007). A randomized controlled trial of acupuncture for osteoarthritis of the knee: Effects of patient-provider communication. Arthritis Care Res. 62 (9): 1229-1236. https://doi.org/10.1002/acr.20225.

American Academy Orthopaedic Surgeons (AAOS). (2013). Distal Radius Fracture (Broken Wrist). Accessed from http://orthoinfo.aaos.org/PDFs/Aoo 412.pdf.

Bashori A, Santoso TB (2009). Perbedaan penambahan diclofenac topikal pada intervensi IRR dan aktif excercise terhadap pengurangan nyeri OA lutut (The difference of the addition of topical diclofenac to the intervention of IRR and active excercise on the reduction of knee pain). J Physiother.
9 (1). https://ejurnal.esaunggul.ac.id/index.php/Fisio/article/view/619.

Bermann BM, et al (2004). Effectiveness of Acupuncture as Adjunctive Therapy in Osteoarthritisof the Knee. Ann Intern Med. 141:901-910

Foster NE et al (2007). Acupuncture as an adjunct to exercise based physiotherapy for osteoarthritis of the knee: randomised controlled trial. Bmj.1-12

Hinmann RS, Mccrory P, Pirrota M, Forbes A, Crossley KM, Williamson E, Kyriakides M, Novy K, Metcalf BR, Harris A, Reddy P, Conaghan PG, Bennel KL. (2014). Acupuncture for Chronic Knee Pain

Ho-Pham LT, Lai TQ, Mai LD, Doan MC, Pham HN, Nguyen (2014). Prevalence of radiographic osteoarthritis of the knee and its relationship to selfreported pain. Journal. Plos.one. 9(4)

Jubb RW, Tukmachi ES, Jones PW, Dempesy E, Waterhouse L, dan Brailsford (2015). A blinded randomised trial of acupuncture (manual and electroacupuncture) compared with a non-penetrating sham for the symptoms of osteoarthritis of the knee. Acupunct Med. 26(2): 69-78. https://doi.org/10.1136/aim.26.2.69.

Haryanto JT (2017). Pengaruh terapi akupunktur jin's 3 needle terhadap penurunan skala nyeri pada pasien nyeri lutut Di dusun sidorejo desa Ngargorejo Kecamatan ngemplak boyolali (The effect of acupuncture therapy with genie 's 3 needles on reducing pain scale in knee pain patients in Sidorejo hamlet, Ngargorejo village, Ngemplak boyolali sub-district). Jurnal Keterapian Fisik. 2(1): 1-61.

Laporan RISKESDAS (2018). Riset Kesehatan Dasar: Badan Penelitian dan Pengembangan Kesehatan Kemenkes 
Susilo et al./ Effect of Acupuncture Therapy on Pain Reduction in Osteoarthritis Patients

RI tahun 2018 (Basic Health Research: Research and Development Agency for Health Ministry of Health of the Republic of Indonesia in 2018).

Lin LL, Li YT, Tu JF, Yang JW, Sun N, Zhang S, Wang TQ, et al. (2018). Effectiveness and feasibility of acupuncture for knee osteoarthritis:a pilot randomized controlled trial. Clin Rehabil. 32(12): 1666-1675. https://doi.org/10.1177/0269215518790632.

Mora JC, Przkora R, Almeida YC (2018). Knee osteoarthritis: pathophysiology and current treatment modalities. $\mathrm{J}$ Pain Res. 11: 2189-2196. https://doi.org/10.2147/jpr.s154002.

Murti B (2018). Prinsip dan Metode Riset Epidemiologi (5th ed) (Principles and Methods of Epidemiological Research (5th ed)). Surakarta: Program Studi Ilmu Kesehatan Masyarakat, Program Pascasarjana, Universitas Sebelas Maret.

Plaster R, Vieira WB, Alencar FAD, Nakano EYN, Liebano RE (2014). Immediate effects of electroacupuncture and manual acupuncture on pain, mobility and muscle strength in patients with knee osteoarthritis: a randomized controlled trial. Acupunct Med. 32(3): 236-241. https://doi.org/10.1136/acupmed-2013-010489.

Riset Kesehatan Dasar (Riskesdas) (2018). Badan Penelitian dan Pengembangan
Kesehatan Kementerian RI tahun 2018 (Ministry of Health Research and Development Agency of the Republic of Indonesia in 2018).

Saputra K, Sudirman S (2009). Akupunktur untuk nyeri dengan pendekatan neurosain (Acupuncture for pain with a neuroscience approach). Jakarta: Sagung Seto.

Scharf HP, Mansmann U, Streitberger K, Witte S, Kramer J, Maier J, Trampisch HJ, Victor N (2016). Acupuncture and Knee Osteoarthritis. Ann Intern Med. 145(1): 12-20. https://doi.org/10.7326/0003-4819-145-1-200607040-00005.

Witt C, Brinkhaus B, Jena S, Linde K, Streng A, Wagenfeil S, Hmmelserger J, Walther HU, Melchar D, Wilich SN (2005). Acupuncture in patients with osteoarthritis of the knee or hip: a randomized, controlled trial with an additional nonrandomized arm. Arthritis Rheum. 54(11): 3485-93. https://doi.org/10.1002/art.22154.

Xu H, Ryan JD, Li K (2007). Clinical investigation into the effectiveness of needleless acupuncture in the management of the symptoms of osteoarthritis of the knee: A preliminary, single-blind and sham-controlled study. Aust J Acupunct Chinese Med. 2(2):9-15. https://dx.doi.org/10.1097\%2Fo1.FCH.oooo324482.78577.of. 